\title{
A Visão Moral dos Profissionais e Suas Implicações para a Humanização da Assistência
}

\author{
Junges, José Roque; Oliveira, Márcia Regina de \\ Universidade do Vale do Rio dos Sinos (Unisinos) — roquejunges@hotmail.com
}

Se para a Política Nacional de Humanização a produção de saúde é sempre produção de subjetividade, tanto de usuários quanto de profissionais, o modo como esses últimos se posicionam subjetivamente na relação com o usuário é fundamental para o alcance das metas da humanização. por isso é importante conhecer como a visão moral subjetiva dos profissionais influencia na humanização das suas práticas de atendimento. OBJETIVO da PESQUISA: analisar a visão moral dos profissionais de uma Unidade Básica de Saúde (UBS) e apontar suas implicações para a prática da humanização da assistência. METODOLOGIA: trata-se de uma investigação de natureza exploratória, com abordagem qualitativa. Os dados foram coletados em quatro sessões de discussão focal com profissionais de uma UBS da cidade de São Leopoldo (RS), tendo cada reunião a duração de uma hora. Fizeram parte do grupo: 1 gestora da unidade, 1 médico, 1 dentista, 2 enfermeiras, 3 técnicas de enfermagem, 1 atendente da portaria, 1 auxiliar de serviços gerais. o roteiro do grupo focal partiu de casos concretos trazidos pelo condutor da discussão ou apresentados pelos profissionais que incluíam as seguintes questões para a discussão: Quais são os direitos do usuário, Qual é a responsabilidade dos profissionais em relação a esses direitos, em que consiste a resolutividade na resposta às necessidades em saúde, em que consiste a ética das práticas do serviço, em que consiste a humanização neste caso concreto. Os dados transcritos foram interpretados pela análise do discurso. RESULTADOS: o principal resultado foi que os profissionais identificaram moral com ter boas intenções no atendimento, sendo os resultados mais uma consequência de procedimentos técnicos do que uma questão ética. Esse resultado aparece analisando a dinâmica do discurso e os termos utilizados. DISCUSSÃO: As diretrizes da Política Nacional de Humanização propõem a corresponsabilidade e a cogestão de profissionais, gestores e usuários, para o alcance dos objetivos da humanização que são a resolutividade e a excelência na prestação dos serviços de saúde. Nesse sentido humanização não é uma questão de caridade, mas corresponde à realização dos direitos do usuário. Conclusão: por isso a ética do profissional não pode estar pautada pela boa intenção, mas deve ser baseada nos resultados, identificando-se com a ética da responsabilidade.

Palavras-chave: Humanização, Ética, Profissionais, Resolutividade, Responsabilidade

Junges, José Roque; Oliveira, Márcia Regina de. A Visão Moral dos Profissionais e Suas Implicações para a Humanização da Assistência. In: Anais do Congresso Internacional de Humanidades \& Humanização em Saúde [= Blucher Medical Proceedings, num.2, vol.1]. São Paulo: Editora Blucher, 2014. ISSN 2357-7282 DOI 10.5151/medpro-cihhs-10269 